\title{
Correction to: Thinking embodiment with genetics: epigenetics and postgenomic biology in embodied cognition and enactivism
}

\author{
Maurizio Meloni ${ }^{1}$ (D) Jack Reynolds ${ }^{2}$ (D)
}

Published online: 13 January 2021

(c) The Author(s) 2021

\section{Correction to: Synthese \\ https://doi.org/10.1007/s11229-020-02748-3}

The article Thinking embodiment with genetics: epigenetics and postgenomic biology in embodied cognition and enactivism, written by Maurizio Meloni and Jack Reynolds, was originally published electronically on the publisher's internet portal on 18 June 2020 without open access. With the author(s)' decision to opt for Open Choice the copyright of the article changed on 6 November 2020 to @The Author(s) 2020 and the article is forthwith distributed under a Creative Commons Attribution.

This article is licensed under a Creative Commons Attribution 4.0 International License, which permits use, sharing, adaptation, distribution and reproduction in any medium or format, as long as you give appropriate credit to the original author(s) and the source, provide a link to the Creative Commons licence, and indicate if changes were made. The images or other third party material in this article are included in the article's Creative Commons licence, unless indicated otherwise in a credit line to the material. If material is not included in the article's Creative Commons licence and your intended use is not permitted by statutory regulation or exceeds the permitted use, you will need to obtain permission directly from the copyright holder. To view a copy of this licence, visit http://creativecommons.org/licen ses/by/4.0/.

The original article can be found online at https://doi.org/10.1007/s11229-020-02748-3.

Maurizio Meloni

Maurizio.meloni@deakin.edu.au

1 Alfred Deakin Institute for Citizenship and Globalization, Deakin University, Melbourne, VIC, Australia

2 Faculty of Arts and Education, Deakin University, 221 Burwood Highway, Burwood, VIC 3125, Australia 
Open Access This article is distributed under the terms of the Creative Commons Attribution 4.0 International License (http://creativecommons.org/licenses/by/4.0/), which permits unrestricted use, distribution, and reproduction in any medium, provided you give appropriate credit to the original author(s) and the source, provide a link to the Creative Commons license, and indicate if changes were made.

Publisher's Note Springer Nature remains neutral with regard to jurisdictional claims in published maps and institutional affiliations. 